\title{
Renewable Energy Technologies for Future and Sustainable Development
}

\author{
Abdeen Omer M* \\ Energy Research Institute (ERI), Nottingham NG7 4EU, United Kingdom \\ *Corresponding author: Abdeen Mustafa Omer, Energy Research Institute (ERI), \\ Nottingham NG7 4EU, United Kingdom, Email: abdeenomer2@yahoo.co.uk
}

\section{Review Article \\ Volume 2 Issue 2}

Received Date: March 22, 2018

Published Date: March 27, 2018

DOI: $10.23880 /$ jenr-16000123

\section{Abstract}

People are relying upon oil for primary energy and this will continue for a few more decades. Other conventional sources may be more enduring, but are not without serious disadvantages. The renewable energy resources are particularly suited for the provision of rural power supplies and a major advantage is that equipment such as flat plate solar driers, wind machines, etc., can be constructed using local resources. Without the advantage results from the feasibility of local maintenance and the general encouragement such local manufacture gives to the build-up of small-scale rural based industry. This communication comprises a comprehensive review of energy sources, the environment and sustainable development. It includes the renewable energy technologies, energy efficiency systems, energy conservation scenarios, energy savings in greenhouses environment and other mitigation measures necessary to reduce climate change. This study gives some examples of small-scale energy converters, nevertheless it should be noted that small conventional, i.e., engines are currently the major source of power in rural areas and will continue to be so for a long time to come. There is a need for some further development to suit local conditions, to minimise spares holdings, to maximise the interchangeability of the engine parts, and of the engine applications. Emphasis should be placed on full local manufacture. It is concluded that renewable environmentally friendly energy must be encouraged, promoted, implemented and demonstrated by a full-scale plant (device) especially for use in remote rural areas.

Keywords: Renewable technologies; Energy efficient systems; Eco-systems; Sustainable development

\section{Introduction}

The move towards a low-carbon cleaner world, driven partly by climate science and partly by the business opportunities it offers, will need the promotion of environmentally friendly alternatives, if an acceptable stabilisation level of atmospheric carbon dioxide is to be achieved. This requires the harnessing and use of natural resources that produce no air pollution or greenhouse gases and provides comfortable coexistence of human, livestock, and plants. This article presents a comprehensive review of energy sources, the development of sustainable technologies to explore these energy sources. It also includes potential renewable energy technologies, energy efficiency systems, energy savings techniques and other mitigation measures 


\section{Journal of Ecology \& Natural Resources}

necessary to reduce climate change. The article concludes with the technical status of the GSHP technologies.

Over millions of years ago, plants have covered the earth, converting the energy of sunlight into living plants and animals, some of which was buried in the depths of the earth to produce deposits of coal, oil and natural gas [1-3]. The past few decades, however, have experienced many valuable uses for these complex chemical substances and manufacturing from them plastics, textiles, fertiliser and the various end products of the petrochemical industry. Indeed, each decade sees increasing uses for these products. Coal, oil and gas, which will certainly be of great value to future generations, as they are to the present, are however non-renewable natural resources. The rapid depletion of these nonrenewable fossil resources need not continue. This is particularly true now as it is, or soon will be, technically and economically feasible to supply all of man's needs from the most abundant energy source of all, the sun. The sunlight is not only inexhaustible, but, moreover, it is the only energy source, which is completely non-polluting [4].

Industry's use of fossil fuels has been largely blamed for warming the climate. When coal, gas and oil are burnt, they release harmful gases, which trap heat in the atmosphere and cause global warming. However, there had been an ongoing debate on this subject, as scientists have struggled to distinguish between changes, which are human induced, and those, which could be put down to natural climate variability. Notably, human activities that emit carbon dioxide $\left(\mathrm{CO}_{2}\right)$, the most significant contributor to potential climate change, occur primarily from fossil fuel production. Consequently, efforts to control $\mathrm{CO}_{2}$ emissions could have serious, negative consequences for economic growth, employment, investment, trade and the standard of living of individuals everywhere.

\section{Energy Sources and Use}

Scientifically, it is difficult to predict the relationship between global temperature and greenhouse gas (GHG) concentrations. The climate system contains many processes that will change if warming occurs. Critical processes include heat transfer by winds and tides, the hydrological cycle involving evaporation, precipitation, runoff and groundwater and the formation of clouds, snow, and ice, all of which display enormous natural variability. The equipment and infrastructure for energy supply and use are designed with long lifetimes, and the premature turnover of capital stock involves significant costs. Economic benefits occur if capital stock is replaced with more efficient equipment in step with its normal replacement cycle. Likewise, if opportunities to reduce future emissions are taken in a timely manner, they should be less costly. Such a flexible approach would allow society to take account of evolving scientific and technological knowledge, while gaining experience in designing policies to address climate change [4].

The World Summit on Sustainable Development in Johannesburg in 2002 [4] committed itself to "encourage and promote the development of renewable energy sources to accelerate the shift towards sustainable consumption and production". Accordingly, it aimed at breaking the link between resource use and productivity. This can be achieved by the following:

- Trying to ensure economic growth does not cause environmental pollution.

- Improving resource efficiency.

- Examining the whole life-cycle of a product.

- Enabling consumers to receive more information on products and services.

- Examining how taxes, voluntary agreements, subsidies, regulation and information campaigns, can best stimulate innovation and investment to provide cleaner technology.

The energy conservation scenarios include rational use of energy policies in all economy sectors and the use of combined heat and power systems, which are able to add to energy savings from the autonomous power plants. Electricity from renewable energy sources is by definition the environmental green product. Hence, a renewable energy certificate system, as recommended by the World Summit, is an essential basis for all policy systems, independent of the renewable energy support scheme. It is, therefore, important that all parties involved support the renewable energy certificate system in place if it is to work as planned. Moreover, existing renewable energy technologies (RETs) could play a significant mitigating role, but the economic and political climate will have to change first. It is now universally accepted that climate change is real. It is happening now, and GHGs produced by human activities are significantly contributing to it. The predicted global temperature increase of between 1.5 and $4.5^{\circ} \mathrm{C}$ could lead to potentially catastrophic environmental impacts [5]. These include sea level rise, increased frequency of extreme weather events, floods, droughts, disease migration from various places and possible stalling of the Gulf Stream. This has led scientists to argue that climate change issues are not ones that politicians can afford to ignore, and policy makers tend to agree [5]. However, reaching international agreements on climate change policies is no trivial task as the difficulty in 


\section{Journal of Ecology \& Natural Resources}

ratifying the Kyoto Protocol and reaching agreement at Copenhagen have justified.

Therefore, the use of renewable energy sources and the rational use of energy, in general, are the fundamental inputs for any responsible energy policy. However, the energy sector is encountering difficulties because increased production and consumption levels entail higher levels of pollution and eventually climate change, with possibly disastrous consequences. At the same time, it is important to secure energy at an acceptable cost in order to avoid negative impacts on economic growth.

To date, renewable energy contributes only as much as $20 \%$ of the global energy supplies worldwide [5]. Over two thirds of this comes from biomass use, mostly in developing countries, and some of this is unsustainable. However, the potential for energy from sustainable technologies is huge. On the technological side, renewables have an obvious role to play. In general, there is no problem in terms of the technical potential of renewables to deliver energy. Moreover, there are very good opportunities for RETs to play an important role in reducing emissions of GHGs into the atmosphere, certainly far more than have been exploited so far. However, there are still some technical issues to address in order to cope with the intermittency of some renewables, particularly wind and solar. Nevertheless, the biggest problem with relying on renewables to deliver the necessary cuts in GHG emissions is more to do with politics and policy issues than with technical ones [6]. For example, the single most important step governments could take to promote and increase the use of renewables is to improve access for renewables to the energy market. This access to the market needs to be under favourable conditions and, possibly, under favourable economic rates as well.

One move that could help, or at least justify, better market access would be to acknowledge that there are environmental costs associated with other energy supply options and that these costs are not currently internalised within the market price of electricity or fuels. This could make a significant difference, particularly if appropriate subsidies were applied to renewable energy in recognition of the environmental benefits it offers. Similarly, cutting energy consumption through end-use efficiency is absolutely essential. This suggests that issues of end-use consumption of energy will have to come into the discussion in the foreseeable future [7]. The end-use consumption can be related to demand side management (DSM), which is available but yet to be applied in developing countries.
However, RETs have the benefit of being environmentally benign when developed in a sensitive and appropriate way with the full involvement of local communities. In addition, they are diverse, secure, locally based and abundant.

In spite of the enormous potential and the multiple benefits, the contribution from renewable energy still lags behind the ambitious claims for it due to the initially high development costs, concerns about local impacts, lack of research funding and poor institutional and economic arrangements [8]. Hence, an approach is needed to integrate renewable energies in a way that meets the rising demand in a cost-effective way.

\section{Role of Energy Efficiency System}

The prospects for development in power engineering are, at present, closely related to ecological problems. Power engineering has harmful effects on the environment, as it discharges toxic gases into the atmosphere and also oil-contaminated and saline waters into rivers, as well as polluting the soil with ash and slag and having adverse effects on living things on account of electromagnetic fields and so on. Thus there is an urgent need for new approaches to provide an ecologically safe strategy. Substantial economic and ecological effects for thermal power projects (TPPs) can be achieved by improvement, upgrading the efficiency of the existing equipment, reduction of electricity loss, saving of fuel, and optimisation of its operating conditions and service life leading to improved access for rural and urban lowincome areas in developing countries through energy efficiency and renewable energies.

Sustainable energy is a prerequisite for global development. Energy-based living standards in developing countries, however, are clearly below standards in developed countries.

Low levels of access to affordable and environmentally sound energy in both rural and urban low-income areas are therefore a predominant issue in developing countries. In recent years many programmes for development aid or technical assistance have been focusing on improving access to sustainable energy, many of them with impressive results. Apart from success stories, however, experience also shows that positive appraisals of many projects evaporate after completion and vanishing of the implementation expert team. Altogether, the diffusion of sustainable technologies such as energy efficiency and renewable energy for cooking, heating, lighting, electrical appliances and building insulation in developing countries has been slow. 


\section{Journal of Ecology \& Natural Resources}

Energy efficiency and renewable energy programmes could be more sustainable and pilot studies more effective and pulse releasing if the entire policy and implementation process was considered and redesigned from the outset [9]. New financing and implementation processes, which allow reallocating financial resources and thus enabling countries themselves to achieve a sustainable energy infrastructure, are also needed.

The links between the energy policy framework, financing and implementation of renewable energy and energy efficiency projects have to be strengthened as well efforts made to increase people's knowledge through training.

\section{Energy Use in Buildings}

Buildings consume energy mainly for cooling, heating and lighting. The energy consumption was based on the assumption that the building operates within ASHRAEthermal comfort zone during the cooling and heating periods [10]. Most of the buildings incorporate energy efficient passive cooling, solar control, photovoltaic, lighting and day lighting, and integrated energy systems. It is well known that thermal mass with night ventilation can reduce the maximum indoor temperature in buildings in summer [11]. Hence, comfort temperatures may be achieved by proper application of passive cooling systems. However, energy can also be saved if an air conditioning unit is used [12]. The reason for this is that in summer, heavy external walls delay the heat transfer from the outside into the inside spaces. Moreover, if the building has a lot of internal mass the increase in the air temperature is slow. This is because the penetrating heat raises the air temperature as well as the temperature of the heavy thermal mass. The result is a slow heating of the building in summer as the maximal inside temperature is reached only during the late hours when the outside air temperature is already low. The heat flowing from the inside heavy walls could be reduced with good ventilation in the evening and night. The capacity to store energy also helps in winter, since energy can be stored in walls from one sunny winter day to the next cloudy one. However, the admission of daylight into buildings alone does not guarantee that the design will be energy efficient in terms of lighting. In fact, the design for increased daylight can often raise concerns relating to visual comfort (glare) and thermal comfort (increased solar gain in the summer and heat losses in the winter from larger apertures). Such issues will clearly need to be addressed in the design of the window openings, blinds, shading devices, heating system, etc. In order for a building to benefit from daylight energy terms, it is a prerequisite that lights are switched off when sufficient daylight is available. The nature of the switching regime; manual or automated, centralised or local, switched, stepped or dimmed, will determine the energy performance. Simple techniques can be implemented to increase the probability that lights are switched off [13]. These include:

- Making switches conspicuous and switching banks of lights independently.

- Loading switches appropriately in relation to the lights.

- Switching banks of lights parallel to the main window wall.

There are also a number of methods, which help reduce the lighting energy use, which, in turn, relate to the type of occupancy pattern of the building [13]. The light switching options include:

- Centralised timed off (or stepped)/manual on.

- Photoelectric off (or stepped)/manual on.

- Photoelectric and on (or stepped), photoelectric dimming.

- Occupant sensor (stepped) on/off (movement or noise sensor).

Likewise, energy savings from the avoidance of air conditioning can be very substantial. Whilst day-lighting strategies need to be integrated with artificial lighting systems in order to become beneficial in terms of energy use, reductions in overall energy consumption levels by employment of a sustained programme of energy consumption strategies and measures would have considerable benefits within the buildings sector. It would perhaps be better to support a climate sensitive design approach that encompasses some elements of the pure conservation strategy together with strategies, which work with the local ambient conditions making use of energy technology systems, such as solar energy, where feasible. In practice, low energy environments are achieved through a combination of measures that include:

- The application of environmental regulations and policy.

- The application of environmental science and best practice.

- Mathematical modelling and simulation.

- Environmental design and engineering.

- Construction and commissioning.

- Management and modifications of environments in use. While the overriding intention of passive solar energy design of buildings is to achieve a reduction in purchased energy consumption. The non-realisation of potential energy benefits is mainly due to the neglect of the 
consideration of post-occupancy user and management behaviour by energy scientists and designers alike. Calculating energy inputs in agricultural production is more difficult in comparison to the industry sector due to the high number of factors affecting agricultural production, as Table 1 shows. However, considerable studies have been conducted in different countries on energy use in agriculture [14-19] in order to quantify the influence of these factors.

\section{Renewable Energy Technologies}

Sustainable energy is the energy that, in its production or consumption, has minimal negative impacts on human health and the healthy functioning of vital ecological systems, including the global environment. It is an accepted fact that renewable energy is a sustainable form of energy, which has attracted more attention during recent years. Increasing environmental interest, as well as economic consideration of fossil fuel consumption and high emphasis of sustainable development for the future helped to bring the great potential of renewable energy into focus. Nearly a fifth of all global power is generated by renewable energy sources, according to a book published by the OECD/IEA [20]. "Renewables for power generation: status and prospects" claims that, at approximately $20 \%$, renewables are the second largest power source after coal (39\%) and ahead of nuclear $(17 \%)$, natural gas $(17 \%)$ and oil $(8 \%)$ respectively. From $1973-2000$ renewables grew at $9.3 \%$ a year and it is predicted that this will increase by $10.4 \%$ a year to 2010 . Wind power grew fastest at $52 \%$ and will multiply seven times by 2010, overtaking biopower and hence help reducing green house gases, GHGs, emissions to the environment.

Table 2 shows some applications of different renewable energy sources. The challenge is to match leadership in GHG reduction and production of renewable energy with developing a major research and manufacturing capacity in environmental technologies (wind, solar, fuel cells, etc.). More than 50\% of the world's area is classified as arid, representing the rural and desert part, which lack electricity and water networks. The inhabitants of such areas obtain water from borehole wells by means of water pumps, which are mostly driven by diesel engines. The diesel motors are associated with maintenance problems, high running cost, and environmental pollution. Alternative methods are pumping by photovoltaic (PV) or wind systems. At present, renewable sources of energy are regional and site specific. It has to be integrated in the regional development plans. Rasslavicius, Grzybek, and Dubrovin (2011) investigated prospects of bioenergy in Lithuania and Ukraine and put emphasis on agricultural waste-forenergy production technologies as well as on impact of bioenergy towards the improvement of the quality of life in rural communities [36]. Guilherme, Luiz, and Legey (2013) investigated energy from sugarcane bagasse in Brazil: An assessment of the productivity and cost of different technological routes [37].

\begin{tabular}{|c|c|c|}
\hline Energy source & Unit & Equivalent energy (MJ) \\
\hline Input & & \\
\hline 1. Human labour & h & 2.3 \\
\hline $\begin{array}{l}\text { 2. Animal labour } \\
\text { Horse }\end{array}$ & & \\
\hline Mule & $\mathrm{h}$ & 10.10 \\
\hline Donkey & h & 4.04 \\
\hline Cattle & $\mathrm{h}$ & 4.04 \\
\hline Water buffalo & $\mathrm{h}$ & 5.05 \\
\hline 3. Electricity & $\stackrel{\mathrm{h}}{\mathrm{c}}$ & 7.58 \\
\hline 4. Diesel & kWh & $\begin{array}{l}11.93 \\
56.31\end{array}$ \\
\hline 5. Chemicals & Litre & 56.31 \\
\hline $\begin{array}{l}\text { fertilisers } \\
\text { Nitrogen }\end{array}$ & $\mathrm{kg}$ & 64.4 \\
\hline $\begin{array}{c}\text { Nitrogen } \\
\mathrm{P}_{2} \mathrm{O}_{5}\end{array}$ & $\mathrm{~kg}$ & 11.96 \\
\hline $\mathrm{K}_{2} \mathrm{O}$ & $\mathrm{kg}$ & 6.7 \\
\hline 6. Seed & & 25 \\
\hline Cereals and pulses & $\begin{array}{l}\mathrm{kg} \\
\mathrm{kg}\end{array}$ & 3.6 \\
\hline Oil seed & $\mathrm{kg}$ & 14.7 \\
\hline Tuber & $\mathrm{kg}$ & 43.3 \\
\hline $\begin{array}{l}\text { Total input } \\
\text { Output }\end{array}$ & & \\
\hline 7. Major products & & 147 \\
\hline Cereal and pulses & $\begin{array}{l}\mathrm{Kg} \\
\mathrm{kg}\end{array}$ & 5.04 \\
\hline Sugar beet & $\mathrm{kg}$ & 0.8 \\
\hline Tobacco & $\mathrm{kg}$ & 11.8 \\
\hline Cotton & $\mathrm{kg}$ & 25 \\
\hline Fruits & $\mathrm{kg}$ & 1.9 \\
\hline Vegetables & $\mathrm{kg}$ & 0.8 \\
\hline Water melon & $\mathrm{kg}$ & 1.9 \\
\hline Onion & $\mathrm{kg}$ & 1.6 \\
\hline Potatoes & $\begin{array}{l}\mathrm{kg} \\
\mathrm{kg}\end{array}$ & $\begin{array}{l}3.6 \\
118\end{array}$ \\
\hline Olive & $\begin{array}{l}\mathrm{kg} \\
\mathrm{kg}\end{array}$ & $\begin{array}{c}11.8 \\
0.8\end{array}$ \\
\hline Tea & & \\
\hline 8. By products & kg & 13.8 \\
\hline Husk & $\mathrm{kg}$ & 12.5 \\
\hline Straw & $\mathrm{kg}$ & 18.0 \\
\hline Cob & $\mathrm{kg}$ & 25.0 \\
\hline $\begin{array}{l}\text { Seed cotton } \\
\text { Total output }\end{array}$ & $\mathrm{kg}$ & 149.04 \\
\hline
\end{tabular}

Table 1: Energy equivalent of inputs and outputs [25].

\section{Solar Energy}

The availability of data on solar radiation is a critical problem. Even in developed countries, very few weather stations have been recording detailed solar radiation data 


\section{Journal of Ecology \& Natural Resources}

for a period of time long enough to have statistical significance. Solar radiation arriving on earth is the most fundamental renewable energy source in nature. It powers the bio-system, the ocean and atmospheric current system and affects the global climate. Reliable radiation information is needed to provide input data in modelling solar energy devices and a good database is required in the work of energy planners, engineers, and agricultural scientists. In general, it is not easy to design solar energy conversion systems when they have to be installed in remote locations. First, in most cases, solar radiation measurements are not available for these sites. Second, the radiation nature of solar radiation makes the computation of the size of such systems difficult. While solar energy data are recognised as very important, their acquisition is by no means straightforward. The measurement of solar radiation requires the use of costly equipment such as pyrheliometers and pyranometers. Consequently, adequate facilities are often not available in developing countries to mount viable monitoring programmes. This is partly due to the equipment cost as well as the cost of technical manpower. Several attempts have, however, been made to estimate solar radiation through the use of meteorological and other physical parameter in order to avoid the use of expensive network of measuring instruments [21-24].

Two of the most essential natural resources for all life on the earth and for man's survival are sunlight and water. Sunlight is the driving force behind many of the RETs. The worldwide potential for utilising this resource, both directly by means of the solar technologies and indirectly by means of biofuels, wind and hydro technologies, is vast. During the last decade interest has been refocused on renewable energy sources due to the increasing prices and fore-seeable exhaustion of presently used commercial energy sources. The most promising solar energy technology are related to thermal systems; industrial solar water heaters, solar cookers, solar dryers for peanut crops, solar stills, solar driven cold stores to store fruits and vegetables, solar collectors, solar water desalination, solar ovens, and solar commercial bakers.

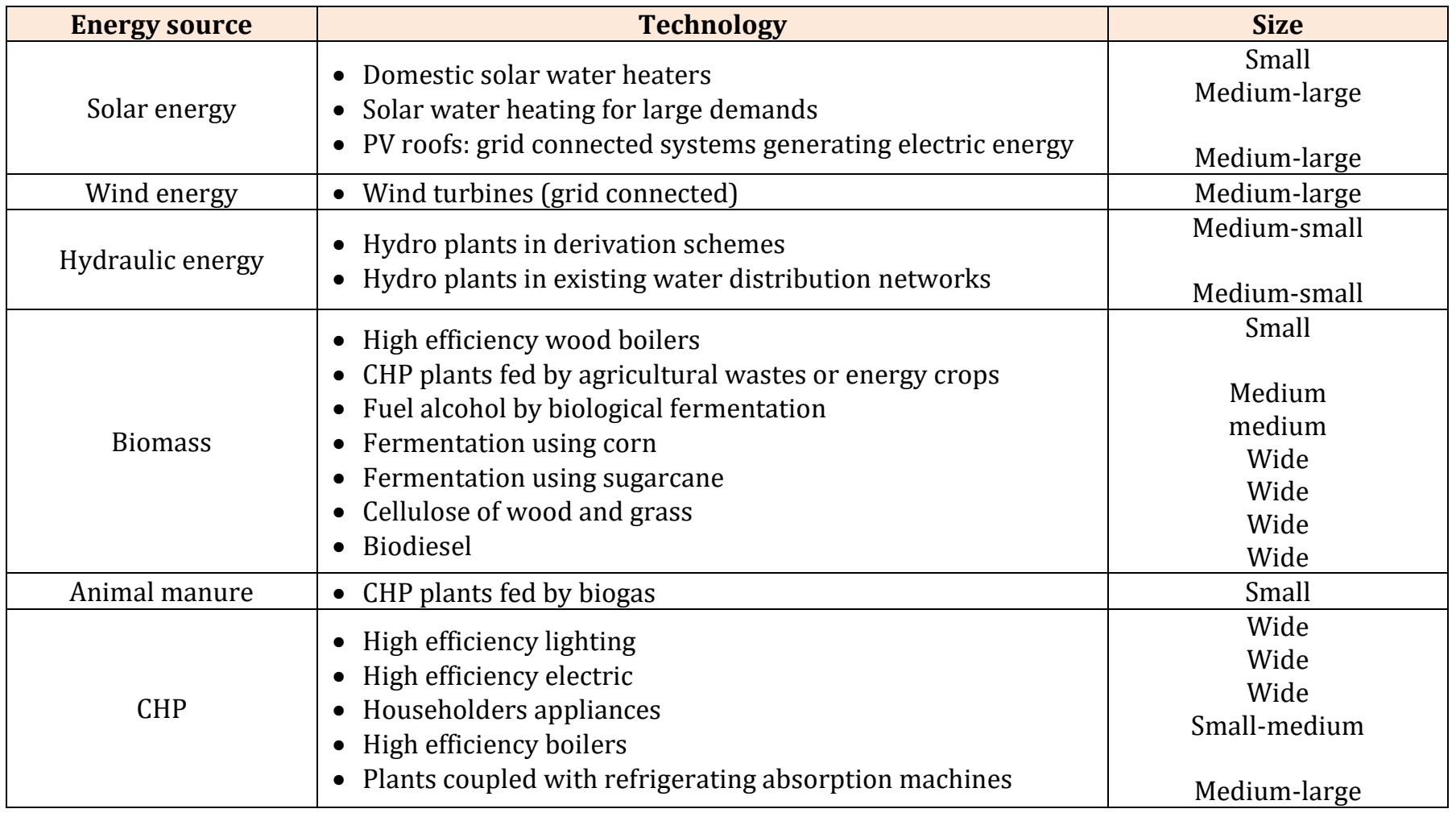

Table 2: Sources of renewable energy.

Solar PV system: solar PV for lighting, solar refrigeration to store vaccines for human and animal use, solar PV for water pumping, solar PV for battery chargers, solar PV for communication network, microwave, receiver stations, radio systems in airports, VHF and beacon radio systems in airports, and educational solar TV posts in villages. Solar pumps are most cost effective for low power requirement (up to $5 \mathrm{~kW}$ ) in remote places. Applications include domestic and livestock drinking water supplies, for which the demand is constant 


\section{Journal of Ecology \& Natural Resources}

throughout the year, and irrigation. However, the suitability of solar pumping for irrigation, though possible, is uncertain because the demand may vary greatly with seasons. Solar systems may be able to provide trickle irrigation for fruit farming, but not usually the large volumes of water needed for wheat growing.

The hydraulic energy required to deliver a volume of water is given by the formula:

$$
\mathrm{E}_{\mathrm{w}}=\rho_{\mathrm{w}} \mathrm{gVH}(1)
$$

Where $E_{w}$ is the required hydraulic energy $\left(\mathrm{kWhday}^{-1}\right) ; \rho_{\mathrm{w}}$ is the water density $\left(\mathrm{kgm}^{-3}\right) ; \mathrm{g}$ is the gravitational acceleration $\left(\mathrm{ms}^{-2}\right)$; V is the required volume of water $\left(\mathrm{m}^{3}\right.$ day $\left.^{-1}\right)$; and $\mathrm{H}$ is the head of water $(\mathrm{m})$.

The solar array power required is given by:

$$
P_{s a}=E_{w} / E_{s r} \eta F(2)
$$

Where: $\mathrm{P}_{\mathrm{sa}}$ is the solar array power $\left(\mathrm{kW}_{\mathrm{p}}\right)$; $\mathrm{E}_{\mathrm{sr}}$ is the average daily solar radiation $\left(\mathrm{kWhm}^{-2}\right.$ day $\left.^{-1}\right) ; \mathrm{F}$ is the array mismatch factor; and $\eta$ is the daily subsystem efficiency.

Substituting Eq. (1) in Eq. (2), the following equation is obtained for the amount of water that can be pumped:

$$
\begin{gathered}
V=P_{s a} E_{s r} \eta F / \rho_{w} g H(3) \\
P_{s a}=1.6 \mathrm{~kW}_{p}, F=0.85, \eta=40 \% .
\end{gathered}
$$

A further increase of PV depends on the ability to improve the durability, performance and the local manufacturing capabilities of PV.

\section{Biomass}

The data required to perform the trade-off analysis simulation of bio-energy resources can be classified according to the divisions given in Table 3, namely the overall system or individual plants, and the existing situation or future development. The effective economical utilisations of these resources are shown in Table 4, but their use is hindered by many problems such as those related to harvesting, collection, and transportation, besides the photo-sanitary control regulations. Biomass energy is experiencing a surge in interest stemming from a combination of factors, e.g., greater recognition of its current role and future potential contribution as a modern fuel, global environmental benefits, its development and entrepreneurial opportunities, etc.

The use of biomass through direct combustion has long been, and still is, the most common mode of biomass utilisation (Table 5). Examples for dry (thermo-chemical) conversion processes are charcoal making from wood (slow pyrolysis), gasification of forest and agricultural residues (fast pyrolysis - this is still in demonstration phase), and of course, direct combustion in stoves, furnaces, etc. Wet processes require substantial amount of water to be mixed with the biomass. Biomass technologies include:

- Carbonisation and briquetting.

- Improved stoves.

- Biogas.

- Improved charcoal.

- Gasification.

- Possible routes of biomass energy development are

\begin{tabular}{|c|c|c|}
\hline $\begin{array}{l}\text { Biomass energy for petroleum } \\
\text { substitution driven by the } \\
\text { following factor }\end{array}$ & $\begin{array}{c}\text { Biomass energy for domestic needs } \\
\text { driven by }\end{array}$ & \begin{tabular}{|c} 
Biomass energy for development \\
driven by
\end{tabular} \\
\hline $\begin{array}{c}\text { Oil price increase } \\
\text { Balance of payment problems, and } \\
\quad \text { economic crisis } \\
\text { Fuel-wood plantations and residue } \\
\text { utilisation } \\
\text { Wood based heat and electricity } \\
\text { Liquid fuels from biomass } \\
\text { Producer gas technology }\end{array}$ & $\begin{array}{c}\text { Population increase } \\
\text { Urbanisation } \\
\text { Agricultural expansion } \\
\text { Fuel-wood crisis } \\
\text { Ecological crisis } \\
\text { Fuel-wood plantations, agro-forestry } \\
\text { Community forestry, and residue utilisation } \\
\text { Improved stoves, and improved charcoal } \\
\text { production }\end{array}$ & $\begin{array}{c}\text { Electrification } \\
\text { Irrigation and water supply } \\
\text { Economic and social development } \\
\text { Fuel-wood plantations } \\
\text { Community forestry } \\
\text { Agro-forestry } \\
\text { Briquettes } \\
\text { Producer gas technology }\end{array}$ \\
\hline
\end{tabular}
shown in Table 5. However, biomass usage and application can generally be divided into the following three categories: 


\section{Journal of Ecology \& Natural Resources}

\begin{tabular}{|c|c|c|}
\hline Criteria & Plant data & System data \\
\hline & Size & Peak load \\
& Life & Load shape \\
& Cost (fixed and variation operation and maintenance) & Capital costs \\
Existing data & Forced outage & Fuel costs \\
& Maintenance & Depreciation \\
& Efficiency & Rate of return \\
& Fuel & Taxes \\
\hline \multirow{3}{*}{ Future data } & Emissions & System lead growth \\
& All of above, plus & Fuel price growth \\
& Capital costs & Fuel import limits \\
& Construction trajectory & Inflation \\
\hline
\end{tabular}

Table 3: Classifications of data requirements.

\begin{tabular}{|c|c|c|}
\hline Subject & Tools & Constraints \\
\hline $\begin{array}{l}\text { Utilisation and land clearance for } \\
\text { agriculture expansion }\end{array}$ & $\begin{array}{l}\text { - Stumpage fees } \\
\text { - Control } \\
\text { - Extension } \\
\text { - Conversion } \\
\text { - Technology }\end{array}$ & $\begin{array}{l}\text { - Policy } \\
\text { - Fuel-wood planning } \\
\text { - Lack of extension } \\
\text { - Institutional }\end{array}$ \\
\hline Utilisation of agricultural residues & $\begin{array}{l}\text { - Briquetting } \\
\text { - Carbonisation } \\
\text { - Carbonisation and briquetting } \\
\text { - Fermentation } \\
\text { - Gasification } \\
\end{array}$ & $\begin{array}{l}\text { - Capital } \\
\text { - Pricing } \\
\text { - Policy and legislation } \\
\text { - Social acceptability }\end{array}$ \\
\hline
\end{tabular}

Table 4: Effective biomass resource utilisation.

Briquetting and carbonisation: Briquetting is the formation of a char (an energy-dense solid fuel source) from otherwise wasted agricultural and forestry residues. One of the disadvantages of wood fuel is that it is bulky with a low energy density and therefore requires transport. Briquette formation allows for a more energydense fuel to be delivered, thus reducing the transportation cost and making the resource more competitive. It also adds some uniformity, which makes the fuel more compatible with systems that are sensitive to the specific fuel input. Charcoal stoves are very familiar to African societies. As for the stove technology, the present charcoal stove can be used, and can be improved upon for better efficiency. This energy term will be of particular interest to both urban and rural households and all the income groups due to its simplicity, convenience, and lower air polluting characteristics. However, the market price of the fuel together with that of its end-use technology may not enhance its early high market penetration especially in the urban low income and rural households.

Charcoal is produced by slow heating wood (carbonisation) in airtight ovens or retorts, in chambers with various gases, or in kilns supplied with limited and controlled amounts of air. The charcoal yield decreased gradually from 42.6 to $30.7 \%$ for the hazelnut shell and from 35.6 to $22.7 \%$ for the beech wood with an increase of temperature from 550 to $1,150 \mathrm{~K}$ while the charcoal yield from the lignin content decreases sharply from 42.5 to $21.7 \%$ until it was at $850 \mathrm{~K}$ during the carbonisation procedures [25]. The charcoal yield decreases as the temperature increases, while the ignition temperature of charcoal increases as the carbonisation temperature increases. The charcoal briquettes that are sold on the commercial market are typically made from a binder and filler.

Improved cook stoves: Traditional wood stoves are commonly used in many rural areas. These can be classified into four types: three stone, metal cylindrical shaped, metal tripod and clay type. Indeed, improvements of traditional cookers and ovens to raise the efficiency of fuel saving can secure rural energy availability, where woody fuels have become scarce. However, planting fast growing trees to provide a constant fuel supply should also be considered. The rural development is essential and economically important since it will eventually lead 


\section{Journal of Ecology \& Natural Resources}

to a better standard of living, people's settlement, and self-sufficiency.

\begin{tabular}{|c|c|c|c|}
\hline Source & Process & Product & End use \\
\hline Agricultural residues & $\begin{array}{c}\text { Direct } \\
\text { Processing } \\
\text { Processing } \\
\text { Carbonisation } \\
\text { Fermentation }\end{array}$ & $\begin{array}{c}\text { Combustion } \\
\text { Briquettes } \\
\text { Carbonisation (small } \\
\text { scale) } \\
\text { Briquettes } \\
\text { Carbonised } \\
\text { Biogas }\end{array}$ & $\begin{array}{c}\text { Rural poor } \\
\text { Urban household } \\
\text { Industrial use } \\
\text { Industrial use } \\
\text { Limited household use } \\
\text { Rural household (self sufficiency) } \\
\text { Urban fuel } \\
\text { Energy services } \\
\text { Household, and industry }\end{array}$ \\
\hline $\begin{array}{l}\text { Agricultural, and animal } \\
\text { residues }\end{array}$ & $\begin{array}{c}\text { Direct } \\
\text { Briquettes } \\
\text { Carbonisation } \\
\text { Carbonisation } \\
\text { Fermentation }\end{array}$ & $\begin{array}{l}\text { Combustion } \\
\text { Direct combustion } \\
\text { Carbonised } \\
\text { Briquettes } \\
\text { Biogas }\end{array}$ & $\begin{array}{c}\text { (Save or less efficiency as wood) } \\
\text { Similar end use devices or improved }) \\
\text { Use } \\
\text { Briquettes use } \\
\text { Use }\end{array}$ \\
\hline
\end{tabular}

Table 5: Agricultural residues routes for development.

Biogas: Biogas technology cannot only provide fuel, but is also important for comprehensive utilisation of biomass forestry, animal husbandry, fishery, agricultural economy, protecting the environment, realising agricultural recycling as well as improving the sanitary conditions, in rural areas. However, the introduction of biogas technology on a wide scale has implications for macro planning such as the allocation of government investment and effects on the balance of payments. Hence, factors that determine the rate of acceptance of biogas plants, such as credit facilities and technical backup services, are likely to have to be planned as part of general macropolicy, as do the allocation of research and development funds [25].

Improved charcoal: Dry cell batteries are a practical but expensive form of mobile fuel that is used by rural people when moving around at night and for powering radios and other small appliances. The high cost of dry cell batteries is financially constraining for rural households, but their popularity gives a good indication of how valuable a versatile fuel like electricity is in rural areas (Table 2.6). However, dry cell batteries can constitute an environmental hazard unless they are recycled in a proper fashion. Tables (6-7) further show that direct burning of fuel-wood and crop residues constitute the main usage of biomass, as is the case with many developing countries. In fact, biomass resources play a significant role in energy supply in all developing countries. However, the direct burning of biomass in an inefficient manner causes economic loss and adversely affects human health. In order to address the problem of inefficiency, research centres around the world, e.g., [25] have investigated the viability of converting the resource to a more useful form of improved charcoal, namely solid briquettes and fuel gas. Accordingly, biomass resources should be divided into residues or dedicated resources, the latter including firewood and charcoal can also be produced from forest residues (Table 7). Whichever form of biomass resource used, its sustainability would primarily depend on improved forest and tree management.

\begin{tabular}{|c|c|}
\hline Energy carrier & Energy end-use \\
\hline Fuel-wood & $\begin{array}{c}\text { Cooking } \\
\text { Water heating } \\
\text { Building materials } \\
\text { Animal fodder preparation }\end{array}$ \\
\hline Kerosene & $\begin{array}{c}\text { Lighting } \\
\text { Ignition fires }\end{array}$ \\
\hline Dry cell batteries & $\begin{array}{c}\text { Lighting } \\
\text { Small appliances }\end{array}$ \\
\hline Animal power & $\begin{array}{c}\text { Transport } \\
\text { Land preparation for farming } \\
\text { Food preparation (threshing) }\end{array}$ \\
\hline Human power & $\begin{array}{c}\text { Transport } \\
\text { Land preparation for farming } \\
\text { Food preparation (threshing) }\end{array}$ \\
\hline
\end{tabular}

Table 6: Energy carrier and energy services in rural areas. 
Gasification: Gasification is based on the formation of a fuel gas (mostly $\mathrm{CO}$ and $\mathrm{H}_{2}$ ) by partially oxidising raw solid fuel at high temperatures in the presence of steam or air. The technology can use wood chips, groundnut shells, sugar cane bagasse, and other similar fuels to generate capacities from $3 \mathrm{~kW}$ to $100 \mathrm{~kW}$. Many types of gasifier designs have been developed to make use of the diversity of fuel inputs and to meet the requirements of the product gas output (degree of cleanliness, composition, heating value, etc.) [25].

\begin{tabular}{|c|c|}
\hline Type of residue & Current use \\
\hline Wood industry waste & Residues available \\
\hline Vegetable crop residues & Animal feed \\
\hline Food processing residue & Energy needs \\
\hline $\begin{array}{c}\text { Sorghum, millet, wheat } \\
\text { residues }\end{array}$ & $\begin{array}{c}\text { Fodder, and building } \\
\text { materials }\end{array}$ \\
\hline Groundnut shells & $\begin{array}{c}\text { Fodder, brick making, direct } \\
\text { fining oil mills }\end{array}$ \\
\hline Cotton stalks & $\begin{array}{c}\text { Domestic fuel considerable } \\
\text { amounts available for short } \\
\text { period }\end{array}$ \\
\hline Sugar, bagasse, molasses & $\begin{array}{c}\text { Fodder, energy need, ethanol } \\
\text { production } \\
\text { (surplus available) }\end{array}$ \\
\hline Manure & $\begin{array}{c}\text { Fertiliser, brick making, } \\
\text { plastering }\end{array}$ \\
\hline
\end{tabular}

Table 7: Biomass residues and current use.

Application of biomass- fuel alcohol produced by biological fermentation is hugely important. There are a lot of fuel alcohol plants in USA (fermentation using corn), and Brazil (fermentation using sugarcane) [37]. Other countries use cellulose of wood and grass. Biodiesel is also a potential renewable fuel which can be extracted initially from several sorts of plant seeds in the flora of southern China. The Netherlands purchased millions of tons of used cooking oil from China for combustion of airplane engines [38].

Biomass and sustainability: A sustainable energy system includes energy efficiency, energy reliability, energy flexibility, fuel poverty, and environmental impacts. A sustainable biofuel has two favourable properties, which are availability from renewable raw material, and its lower negative environmental impact than that of fossil fuels. Global warming, caused by $\mathrm{CO}_{2}$ and other substances, has become an international concern in recent years. To protect forestry resources, which act as major absorbers of $\mathrm{CO}_{2}$, by controlling the ever-increasing deforestation and the increase in the consumption of wood fuels, such as firewood and charcoal, is therefore an urgent issue. Given this, the development of a substitute fuel for charcoal is necessary. Briquette production technology, a type of clean coal technology, can help prevent flooding and serve as a global warming countermeasure by conserving forestry resources through the provision of a stable supply of briquettes as a substitute for charcoal and firewood.

There are many emerging biomass technologies with large and immediate potential applications, e.g., biomass gasifier/gas turbine (BGST) systems for power generation with pilot plants, improved techniques for biomass harvesting, transportation and storage. Gasification of crop residues such as rice husks, groundnut shells, etc., with plants already operating in China, India, and Thailand. Treatment of cellulosic materials by steam explosion which may be followed by biological or chemical hydrolysis to produce ethanol or other fuels, cogeneration technologies, hydrogen from biomass, striling energies capable of using biomass fuels efficiently, etc. Table 8 gives a view of the use of biomass and its projection worldwide.

However, a major gap with biomass energy is that research has usually been aimed at obtaining supply and consumption data, with insufficient attention and resources being allocated to basic research, to production, harvesting and conservation processes. Biomass has not been closely examined in terms of a substitute for fossil fuels compared to carbon sequestration and overall environmental benefits related to these different approaches. To achieve the full potential of biomass as a feedstock for energy, food, or any other use, requires the application of considerable scientific and technological inputs [25-26]. However, the aim of any modern biomass energy systems must be:

(1) To maximise yields with minimum inputs.

(2) Utilise and select adequate plant materials and processes.

(3) Optimise use of land, water, and fertiliser.

(4) Create an adequate infrastructure and strong R\&D base. 


\section{Journal of Ecology \& Natural Resources}

\begin{tabular}{|c|c|c|c|c|}
\hline \multicolumn{5}{|c|}{ Region 2011 } \\
\hline & Biomass & Conventional Energy & Total & Share of Biomass (\%) \\
\hline Africa & 205 & 136 & 341 & 60 \\
\hline China & 206 & 649 & 855 & 24 \\
\hline East Asia & 106 & 316 & 422 & 25 \\
\hline Latin America & 73 & 342 & 416 & 18 \\
\hline South Asia & 235 & 188 & 423 & 36 \\
\hline Total developing countries & 825 & 1632 & 2456 & 1 \\
\hline Other non-OECD countries & 24 & 1037 & 1061 & 24 \\
\hline Total non-OECD countries & 849 & 2669 & 3518 & 3 \\
\hline OECD countries & 81 & 3044 & 3125 & $\mathbf{1 4}$ \\
\hline World & $\mathbf{9 3 0}$ & $\mathbf{5 7 1 3}$ & $\mathbf{6 6 4 3}$ & \\
\hline \multicolumn{2}{|c|}{ Region $\mathbf{2 0 2 0}$} & & Total & Share of Biomass (\%) \\
\hline Africa & Biomass & Conventional Energy & 631 & 59 \\
\hline China & 371 & 266 & 1748 & 13 \\
\hline East Asia & 224 & 1524 & 931 & 13 \\
\hline Latin America & 118 & 813 & 787 & 35 \\
\hline South Asia & 81 & 706 & 799 & 22 \\
\hline Total developing countries & 276 & 523 & 4896 & 1 \\
\hline Other non-OECD countries & 1071 & 3825 & 1695 & 17 \\
\hline Total non-OECD countries & 1097 & 1669 & 6591 & \\
\hline OECD countries & 96 & 5494 & 3968 & \\
\hline World & $\mathbf{1 1 9 3}$ & $\mathbf{9 3 6 5}$ & $\mathbf{1 0 5 5 8}$ & $\mathbf{1 1}$ \\
\hline
\end{tabular}

Table 8: Final energy projections including biomass (Mtoe) [27].

An afforestation programme appears an attractive option for any country to pursue in order to reduce the level of atmospheric carbon by enhancing carbon sequestration in the nation's forests, which would consequently mitigate climate change. However, it is acknowledged that certain barriers need to be overcome if the objectives are to be fully achieved. These include the followings.

- Low level of public awareness of the economic/environmental benefits of forestry.

- The generally low levels of individuals' income.

- Pressures from population growth.

- The land tenural system, which makes it difficult (if at all possible) for individuals to own or establish forest plantations.

- Poor pricing of forest products especially in the local market.

- Inadequate financial support on the part of governments.

- Weak institutional capabilities of the various Forestry Departments as regards technical manpower to effectively manage tree plantations.

However, social policy conditions are also critical. This is still very much lacking particularly under developing countries conditions. During the 1970s and 1980s different biomass energy technologies were perceived in sub-Saharan Africa as a panacea for solving acute problems. On the account of these expectations, a wide range of activities and projects were initiated. However, despite considerable financial and human efforts, most of these initiatives have unfortunately been a failure.

Therefore, future research efforts should concentrate on the following areas.

- Directed $\mathrm{R}$ and $\mathrm{D}$ in the most promising areas of biomass to increase energy supply and to improve the technological base.

- Formulate a policy framework to encourage entrepreneurial and integrated process.

- Pay more attention to sustainable production and use of biomass energy feedstocks, methodology of conservation and efficient energy flows.

- More research aimed at pollution abatement.

- Greater attentions to interrelated socio-economic aspects.

- Support R and D on energy efficiency in production and use.

- Improve energy management skills and take maximum advantage of existing local knowledge. 
- Closely examine past successes and failures to assist policy makers with well-informed recommendations.

\section{Wind Energy}

Water is the most natural commodity for the existence of life in the remote desert areas. However, as a condition for settling and growing, the supply of energy is the second priority. The high cost and the difficulties of mains power line extensions, especially to a low populated region can divert attention to the utilisation of more reliable and independent sources of energy like renewable wind energy.Accordingly, the utilisation of wind energy, as a form of energy, is becoming increasingly attractive and is being widely used for the substitution of oil-produced energy, and eventually to minimise atmospheric degradation. Indeed, utilisation of renewables, such as wind energy, has gained considerable momentum since the oil crises of the 1970s. Wind energy is non-depleting, site-dependent, non-polluting, and a potential source of the alternative energy option. Wind power could supply $12 \%$ of global electricity demand by 2020, according to a report by European Wind Energy Association and Greenpeace. Wind energy can and will constitute a significant energy resource when converted into a usable form (see Figure 1).

As Figure 1 illustrates, information sharing is a fourstage process and effective collaboration must also provide ways in which the other three stages of the 'renewable' cycle: gather, convert and utilise, can be integrated. Efficiency in the renewable energy sector translates into lower gathering, conversion and utilisation (electricity) costs. A great level of installed capacity has already been achieved. Figure 2 clearly shows that the offshore wind sector is developing fast, and this indicates that wind is becoming a major factor in electricity supply with a range of significant technical, commercial and financial hurdles to be overcome.

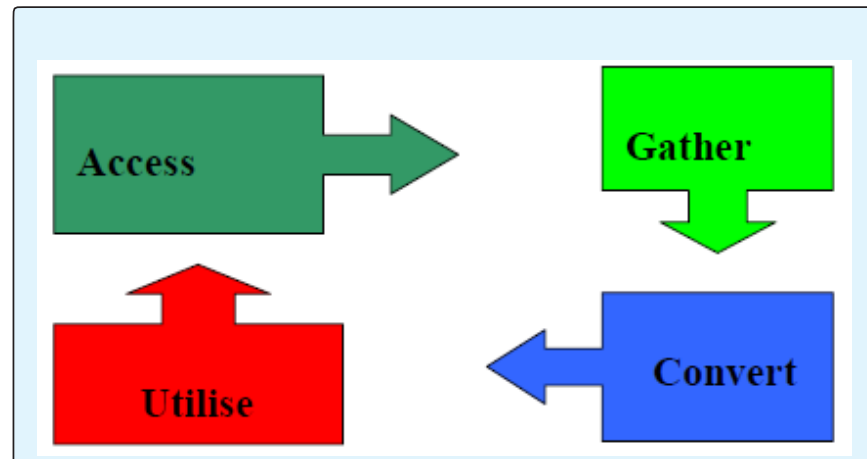

Figure 1: The renewable cycle.
Economic projections are difficult at the best of times, when economies are relatively stable and a reference 'business as usual' case can be used. However, there are numerous signals that the world faces very turbulent economic conditions for a while - a credit crunch may make some project finance difficult and the shortage of raw materials could lead to supply chain difficulties.

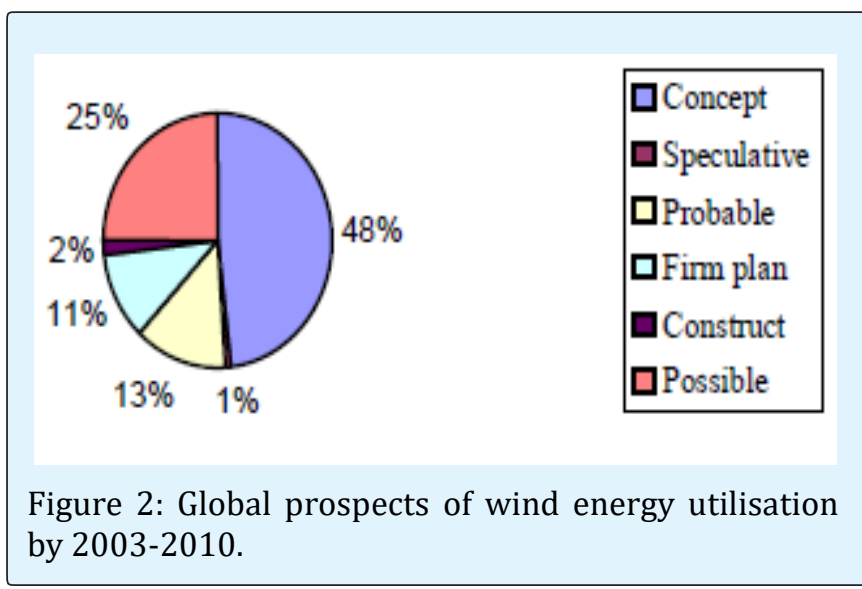

The offshore wind industry has the potential for a very bright future and to emerge as a new industrial sector, as Figure 3 implies. The speed of turbine development is such that more powerful models would supersede the original specification turbines in the time from concept to turbine order. Levels of activities are growing at a phenomenal rate (Figure 4), new prospects developing, new players entering, existing players growing in experience, technology evolving and political will appears to support the sector. The provision of pumped clean water is one of the best ways to improve health and increase the productive capacity of the population. Rural access to clean water is best achieved through pumping from underground water aquifers rather than using surface water sources, which are often polluted.

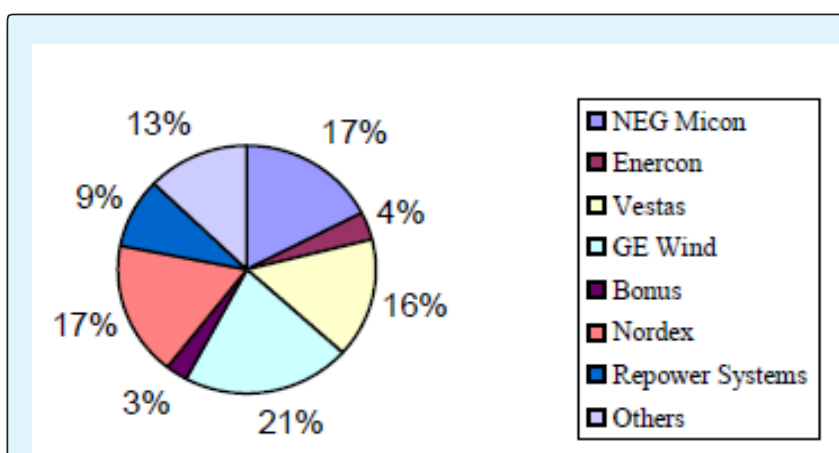

Figure 3: Turbines share for 2003-2010. 


\section{Journal of Ecology \& Natural Resources}

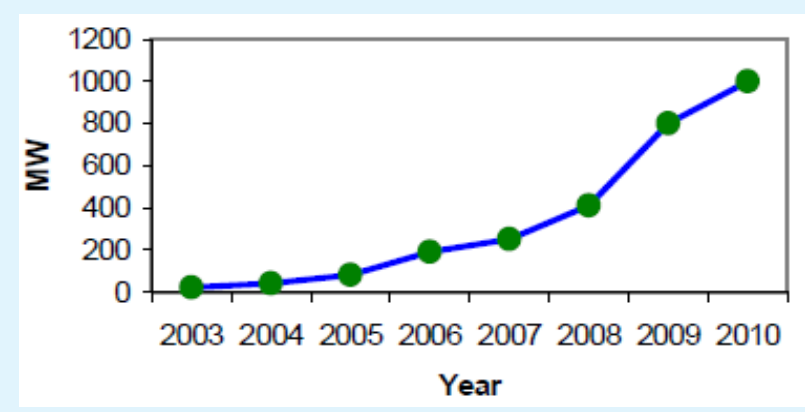

Figure 4: Average windfarm capacity 2003-2010 (Mega watts, MW).

\section{Discussion}

People rely upon oil for primary energy and this for a few more decades. Other conventional sources may be more enduring, but are not without serious disadvantages [27-38]. The renewable energy resources are particularly suited for the provision of rural power supplies and a major advantage is that equipment such as flat plate solar driers, wind machines, etc., can be constructed using local resources and without the advantage results from the feasibility of local maintenance and the general encouragement such local manufacture gives to the build up of small-scale rural based industry. This chapter comprises a comprehensive review of energy sources, the environment and sustainable development. It includes the renewable energy technologies, energy efficiency systems, energy conservation scenarios, energy savings in greenhouses environment and other mitigation measures necessary to reduce climate change. This study gives some examples of small-scale energy converters, nevertheless it should be noted that small conventional, i.e., engines are currently the major source of power in rural areas and will continue to be so for a long time to come. There is a need for some further development to suit local conditions, to minimise spares holdings, to maximise interchangeability both of engine parts and of the engine application. Emphasis should be placed on full local manufacture. It is concluded that renewable environmentally friendly energy must be encouraged, promoted, implemented and demonstrated by full-scale plant (device) especially for use in remote rural areas.

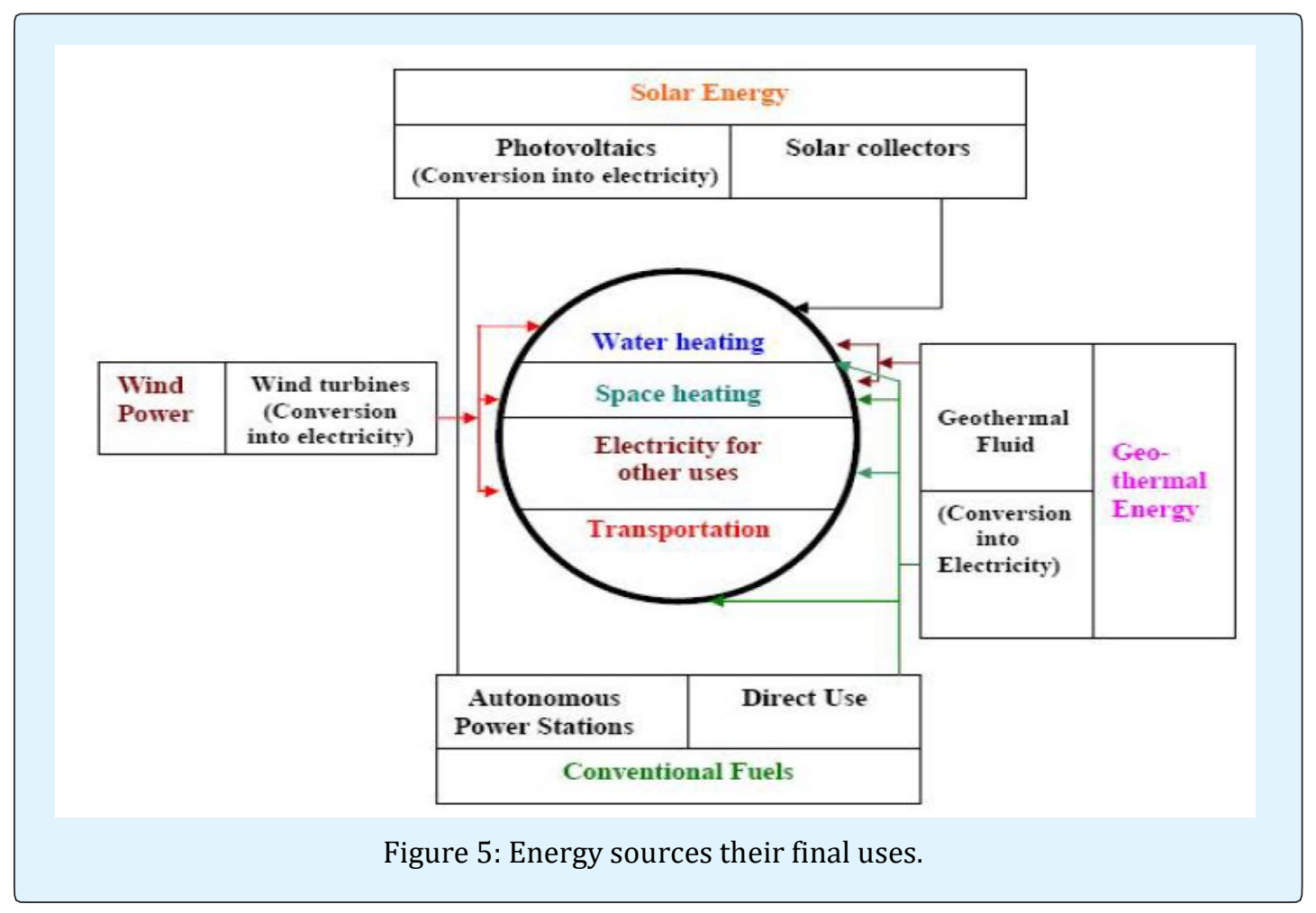

The communication reviews various options of renewable energy sources that are possibly be applied to rural based energy needs which may wholly or partly replace the conventional sources of energy. Sustainable energy is a prerequisite for development. Energy-based living standards in developing countries, however, are clearly below standards in developed countries. Low levels of access to affordable and environmentally sound 
energy in both rural and urban low-income areas are therefore a predominant issue in developing countries. In recent years many programmes for development aid or technical assistance have been focusing on improving access to sustainable energy, many of them with impressive results. Apart from success stories, however, experience also shows that positive appraisals of many projects evaporate after completion and vanishing of the implementation expert team. Altogether, the diffusion of sustainable technologies such as energy efficiency and renewable energy for cooking, heating, lighting, electrical appliances and building insulation in developing countries has been slow [39-31]. Energy efficiency and renewable energy programmes could be more sustainable and pilot studies more effective and pulse releasing if the entire policy and implementation process was considered and redesigned from the outset. New financing and implementation processes, which allow reallocating financial resources and thus enabling countries themselves to achieve a sustainable energy infrastructure, are also needed. The links between the energy policy framework, financing and implementation of renewable energy and energy efficiency projects have to be strengthened and as well as efforts made to increase people's knowledge through training. Different sources of energy, which can be used for different final uses. Those sources are: wind power, solar energy, geothermal energy, the existing electricity production system and the conventional fuels with direct use (Figure 5). The main categories of final uses are: transportation, space heating, water heating and electricity for other uses [40-41].

\section{Conclusions}

There is strong scientific evidence that the average temperature of the earth's surface is rising. This is a result of the increased concentration of carbon dioxide and other GHGs in the atmosphere as released by burning fossil fuels. This global warming will eventually lead to substantial changes in the world's climate, which will, in turn, have a major impact on human life and the built environment. Therefore, effort has to be made to reduce fossil energy use and to promote green energy, particularly in the building sector. Energy use reductions can be achieved by minimising the energy demand, rational energy use, recovering heat and the use of more green energy. This study was a step towards achieving this goal. The adoption of green or sustainable approaches to the way in which society is run is seen as an important strategy in finding a solution to the energy problem. The key factors to reducing and controlling $\mathrm{CO}_{2}$, which is the major contributor to global warming, are the use of alternative approaches to energy generation and the exploration of how these alternatives are used today and may be used in the future as green energy sources. Even with modest assumptions about the availability of land, comprehensive fuel-wood farming programmes offer significant energy, economic and environmental benefits. These benefits would be dispersed in rural areas where they are greatly needed and can serve as linkages for further rural economic development. The nations as a whole would benefit from savings in foreign exchange, improved energy security, and socio-economic improvements. With a nine-fold increase in forest plantation cover, a nation's resource base would be greatly improved. The international community would benefit from pollution reduction, climate mitigation, and the increased trading opportunities that arise from new income sources. The non-technical issues, which have recently gained attention, include: (1) Environmental and ecological factors, e.g., carbon sequestration, reforestation and revegetation. (2) Renewables as a $\mathrm{CO}_{2}$ neutral replacement for fossil fuels. (3) Greater recognition of the importance of renewable energy, particularly modern biomass energy carriers, at the policy and planning levels. (4) Greater recognition of the difficulties of gathering good and reliable renewable energy data, and efforts to improve it. (5) Studies on the detrimental health efforts of biomass energy particularly from traditional energy users.

\section{Recommendations}

- Launching of public awareness campaigns among local investors particularly small-scale entrepreneurs and end users of RETs to highlight the importance and benefits of renewable, particularly solar, wind, and biomass energies.

- Amendment of the encouragement of investment act, to include furthers concessions, facilities, tax holidays, and preferential treatment to attract national and foreign capital investment.

- Allocation of a specific percentage of soft loans and grants obtained by governments to augment budgets of $(\mathrm{R} \& \mathrm{D})$ related to manufacturing and commercialisation of RETs.

- Governments should give incentives to encourage the household sector to use renewable energy instead of conventional energy.

- Execute joint investments between the private sector and the financing entities to disseminate the renewable with technical support from the research and development entities.

- Availing of training opportunities to personnel at different levels in donor countries and other developing countries to make use of their wide 


\section{Journal of Ecology \& Natural Resources}

experience in application and commercialisation of RETs particularly renewable energy.

- The governments should play a leading role in adopting renewable energy devices in public institutions, e.g., schools, hospitals, government departments, police stations, etc., for lighting, water pumping, water heating, communication and refrigeration.

- Encouraging the private sector to assemble, install, repair and manufacture renewable energy devices via investment encouragement and more flexible licensing procedures.

\section{References}

1. Cantrell J, Wepfer W (1984) Shallow Ponds for Dissipation of Building Heat: A case Study. ASHRAE Transactions 90 (1): 239-246.

2. ASHRAE (1995) Commercial/Institutional Ground Source Heat Pump Engineering Manual. American Society of heating, Refrigeration and Air-conditioning Engineers, Inc. Atlanta, GA: USA.

3. Kavanaugh S, Rafferty K (1997) Ground source heat pumps. Design of Geothermal Systems for Commercial and Institutional Buildings. American Society of heating, Refrigeration and Air-conditioning Engineers, Inc. Atlanta, GA: USA.

4. United Nations (2003) World urbanisation project: the 2002 revision. New York: The United Nations Population Division.

5. The United Nations Framework Convention on Climate Change (UNFCCC) (2009) The draft of the Copenhagen Climate Change Treaty. pp: 3-181.

6. Rees WE (1999) The built environment and the ecosphere: a global perspective. Building Research and information 27(4-5): 206-220.

7. Bos E, My T, Vu E, Bulatao R (1994) World population projection: 1994-95. Baltimore and London: World Bank, John Hopkins University Press.

8. Duchin F (1995) Global scenarios about lifestyle and technology, the sustainable future of the global system. Tokyo: United Nations University.

9. Givoni B (1998) Climate consideration in building and urban design. New York: Van Nostrand Reinhold.

10. Ashrae (1993) Energy efficient design of new building except new low-rise residential buildings. BSRIASHRAE proposed standards 90-2P-1993, alternative GA. American Society of Heating, Refrigerating, and Air Conditioning Engineers Inc., USA.

11. Kammerud R, Ceballos E, Curtis B, Place W, Anderson B (1984) Ventilation cooling of residential buildings. ASHRAE Trans: 90 Part 1B.

12. Shaviv E (1989) The influence of the thermal mass on the thermal performance of buildings in summer and winter. In: Steemers TC, Palz W (Eds.), Science and Technology at the service of architecture. Dordrecht: Kluwer Academic Publishers, pp: 470-472.

13. Singh J (2000) On farm energy use pattern in different cropping systems in Haryana, India. Germany: International Institute of ManagementUniversity of Flensburg, Sustainable Energy Systems and Management, Master of Science.

14. Caeedac (2000) A descriptive analysis of energy consumption in agriculture and food sector in Canada. Final Report.

15. Yaldiz O, Ozturk H, Zeren Y (1993) Energy usage in production of field crops in Turkey. In: $5^{\text {th }}$ International Congress on Mechanisation and Energy Use in Agriculture. Turkey: Kusadasi, pp: 11-14.

16. Dutt B (1982) Comparative efficiency of energy use in rice production. Energy 6: 25 .

17. Baruah D (1995) Utilisation pattern of human and fuel energy in the plantation. J Agriculture and Soil Science 8(2): 189-192.

18. Thakur C, Mistra B (1993) Energy requirements and energy gaps for production of major crops in India. Agricultural Situation of India 48: 665-689.

19. Wu J, Boggess W (1999) The optimal allocation of conservation funds. J Environmental Economic Management 38(3): 302-321.

20. OECD/IEA (2004) Renewables for power generation: status and prospect. UK.

21. Duffie JA, Beckman WA (1980) Solar Engineering of Thermal Processes. New York: J Wiley and Sons.

22. Sivkov SI (1964a) To the methods of computing possible radiation in Italy. Trans. Main Geophys Obs 160. 
23. Sivkov SI (1964b) On the computation of the possible and relative duration of sunshine. Trans Main Geophys Obs 160.

24. Barabaro S, Coppolino S, Leone C, Sinagra E (1978) Global solar radiation in Italy. Solar Energy 20: 431438.

25. Hall O, Scrase J (1998) Will biomass be the environmentally friendly fuel of the future? Biomass and Bioenergy 15(4-5): 357-367.

26. Pernille M (2004) Feature: Danish lessons on district heating. Energy Resource Sustainable Management and Environmental 16-17.

27. D’Apote SL (1998) IEA biomass energy analysis and projections. In: Proceedings of Biomass Energy Conference: Data, analysis and Trends, Paris: OECD, pp: 23-24.

28. Abdeen MO (2008a) Energy, environment and sustainable development. Renewable and Sustainable Energy Reviews 12(9): 2265-2300.

29. Omer AM (2008a) Energy demands for heating and cooling equipment systems and technology advancement. Natural Resources: Economics, Management and Policy 131-165.

30. Abdeen MO (2008b) Ground-source heat pumps systems and applications. Renewable and Sustainable Energy Reviews 12(2): 344-371.

31. Abdeen MO (2007) Review: Organic waste treatment for power production and energy supply. J Cell Animal Biology 1(2): 034-047.

32. Omer AM (2008c) Energy demand for heating and cooling equipment systems and technology advancements. In: Natural Resources: Economics, Management and Policy: 131-165.
33. Abdeen MO (2008d) Green energies and the environment. Renewable and Sustainable Energy Reviews 12(7): 1789-1821.

34. Abdeen MO (2012a) Opportunities for sustainable low carbon energy research development and applications. Cooling India 7(10): 60-81.

35. Abdeen MO (2012b) Biomass energy resources utilisation and waste management. Agricultural Science 3(1): 124-145.

36. Rasslavicius L, Grzybek A, Dubrovin V (2011) Bioenergy in Ukraine - possibilities of rural development and opportunities for local communities. J Energy Policy 39(6): 3370-3379.

37. Guilherme AD, Luiz FL, Legey AM (2013) Energy from sugarcane bagasse in Brazil: An assessment of the productivity and cost of different technological routes. Renewable and Sustainable Energy Reviews, 21: 356-364.

38. Cihan G, Dursun B, Bora A, Erkan S (2009) Importance of biomass energy as alternative to other sources in Turkey. Energy Policy 37(2): 424-431.

39. Abotah R, Daim TU (2017) Towards building a multi perspective policy development framework for transition into renewable energy. Sustainable Energy Technologies and Assessments 21: 67-88.

40. Aljerf L, Choukaife AE (2016) Sustainable development in Damascus University: A survey of internal stakeholder Views. J Environmental Studies 2(2): 1-12.

41. Mekhilef S, Faramarzi SZ, Saidur R, Salam Z (2013) The application of solar technologies for sustainable development of agricultural sector. Renewable and Sustainable Energy Reviews 18: 583-594. 